\title{
THE EFFECT OF TOPIC SELECTION ON WRITING FLUENCY AMONG JAPANESE HIGH SCHOOL STUDENTS
}

\author{
Sarah Lin Lubold \\ Sarah Forbes \\ lan Stevenson \\ Kanazawa Technical College, Japan \\ sarah.lubold@gmail.com
}

Article received: 13 April 2015

Final proof received: 27 January 2016

\begin{abstract}
Written fluency and fluency building activities have been shown to promote linguistic choice and student voice development, increased ability to express ideas using complex grammatical structures and greater intrinsic motivation in English language learners. Since the 1970's, process-oriented writing has been emphasized, yielding an amplified focus on meaning of student content over linguistic form precision. Current research of writing fluency must delve deeper into questions of student ownership of topic and the outcomes for low-risk activities that support fluency practice and encourage confidence building in students. The purpose of this replication study is to further explore previous findings on the effects of topic selection on writing fluency for high school English as foreign language learners. Building off of the work of Bonzo (2008), this study focused on a timed, non-graded writing activity administered to groups of Japanese engineering students in three departments: mechanical, electrical, and global engineering. The six subsequent samples for each participating student were analyzed using online text-analysis for total and unique word counts, providing data used to perform a t-test. Responses to bi-lingual student questionnaires, with prompts on self-perceived written English ability, self-efficacy and strategies for success while writing, provided additional insight into the facets of fluency. The results of these writing sessions offer both confirmation of and contrast to Bonzo's original work, demonstrate increased student meaning making, and support the use of free writing activities in English language classrooms as a means by which student written fluency may be improved.
\end{abstract}

Keywords: fluency, EFL writing, free writing, topic selection

Fluency in language use is an integral part of language learner development. Nation (1996) argues that fluency building activities are essential to a successful language classroom. Housen and Kuiken (2009) state that "fluency is primarily related to learners' control over their linguistic L2 knowledge, as reflected in the speed and ease with which they access relevant L2 information to communicate meaning in real time" (p. 461 - 462). Activities that foster fluency provide students opportunities to take risks with language and ask them to make their own choices in how they use language. In many (EFL) learning contexts, there is a tendency to focus on written form and accuracy at the cost of communicative and fluency focused writing activities. Bonzo (2008) states "learners often 'hold back' and avoid taking chances with less familiar forms for fear of diminished accuracy, thus not only producing less complex writing but also less writing overall" (p. 723). This tendency in the Japanese EFL environment is fostered through writing instruction that focuses mainly on accuracy (Connor-Linton, 1995; Kobayakawa, 2011). This discrepancy between learner needs and writing instruction in practice gives rise to a recurring debate.
Writing emerged as a distinct area of concern and discussion in the field of English as a second language learning and teaching in the post-World War II era United States, where a growing number of international students were enrolling in higher education institutions. These students arrived in colleges and university lacking the necessary writing skills to successfully complete coursework and required remedial writing instruction to prepare them for the standards of university level composition (Matsuda, 2003). Matsuda (2003) states that in the 1960s, there was considerable debate between those who favored the integration of free writing exercises to prepare students for "original discourse" and "as a way of developing fluency", such as Erazmus (1960) and Brière (1966) and those who supported the "use of controlled composition, an approach that focused on sentence-level structure" and eliminated the probability of errors, such as Pincas (1962, p. 19). The latter approach was a result of extending aspects of the audiolingual method from oral production to written production (Matsuda, 2003).

In support of his argument to forgo strict compliance with accuracy in favor of fluency 
building writing activities, Brière aptly observed the range of learners that exists within a language classroom at the intermediate level:

\begin{abstract}
At one end of the continuum, we have the student who can only communicate extremely elementary ideas in short, choppy sentences, and at the other end we have the student who can express himself in writing, within certain obvious limitations, quite fluently. Within this range there is always the student who may have a rather sizable vocabulary, be able to express orally some rather complex ideas, and yet, 'freeze up' or 'block' when asked to write some of the ideas he has just been expressing orally. Frequently, such a student is concerned with grammatical 'correctness' of his composition, and his written output thus becomes so extremely limited in quantity, that he never manages to develop an idea to any degree of complexity (1966, p. 141).
\end{abstract}

Brière was arguing for language classrooms that integrate student-driven written discourse that allows learners ownership of their writing and, in turn, builds fluency. This sentiment was later echoed by the work of Bonzo (2008), as well as supported by research into the role of errors in writing development and the effects of different types of feedback on student work (Reichelt, 2001; Robb, Ross, \& Shortreed, 1986). Despite evidence that fluency focused writing exercises provide opportunities for students to gain confidence in their language abilities and produce meaningful texts, writing instruction has predominantly been focused on controlled and guided writing tasks (Matsuda, 2003).

In the $1970 \mathrm{~s}$, there was a paradigm shift in the focus of second language writing from the features of L2 written text, to the process of writing, which allowed for more utilization of fluency building exercises (Matsuda, 2003). While process-writing theory was increasingly incorporated into writing course methodology in native and second language writing courses in the U.S., it was seemingly absent from foreign language curriculum and classrooms (Heilenman, 1991). This may be due, in part, to recommendations by early proponents of the approach, such as Zamel \& Ommagio (as cited in Matsuda, 2003 \& Heilenman, 1991) that processwriting techniques be used primarily with advanced L2 learners. While many foreign language classrooms are comprised of novice language learners, Heilenman (1991), and Bonzo (2008) argue that beginning writers can also benefit from process-oriented approaches. These should include writing activities that build fluency through nongraded writing where the focus is on meaningmaking, not on correct or accurate use of specific pre-taught or practiced forms. Research has also shown that exercises that bring about increased fluency correlate to increased grammatical complexity (Arevart \& Nation, 1991; Bonzo, 2008; Dickinson, 2014). Nation (1996) argues that "as the ease increases with which learners make use of what they know, then they are able to give more attention to the quality of what they use" (p. 10).

While practices that foster student fluency in the target language are seen as an integral part of modern language teaching, there has been, and continues to be a debate over the definition of written fluency and how it should be measured. Bruton \& Kirby (1987) state that rate of writing, length of writing, and a "sense of authority and confidence as reflected in the writer's voice contributes to a sense of fluency" (p. 89). They argue that "written fluency is a powerful construct which encourages writers to continue to develop a range of strategies, forms, procedures, and processes as they grow as thinkers and constructors of knowledge" (p. 90). Bruton \& Kirby (1987) cite Perkin's three conceptualizations of productive fluency as an all-encompassing lens by which to view written fluency. These three types of fluency are "1) test fluency, the ability to generate ideas under test conditions, 2) process fluency, the ability to continue to process despite numerous revisions, and 3) product fluency" which can be interpreted as the swift composition of quality writing without planning or revision (p. 90). They further purport that:

When any series of procedures is presented as the format for successful writing, it robs students of authority and control over the creation of the pieces of writing and over the discovery of knowledge associated with writing, factors crucial to a developing sense of written fluency (p. 90).

When viewed in this way, there is perhaps a more pertinent point tied to the process of free writing that involves the power of student voice and choice. Free composition exercises allow students to dictate the direction and focus of their writing and this possibility as a means for increasing production and engagement finds credence in wider work developed in the psychology of motivation and learning (Perlmuter \& Monty, 1977, p. 729). Providing choice has often been used as a means to increase intrinsic motivation, and "much research has indeed demonstrated that individuals offered choice will show more enjoyment of, better performance on, and greater persistence at a variety of activities" (Cordova \& Lepper,1996 p. 716).

In this way, the work of Bonzo (2008) looks at the potential influence of student agency during topic selection on writing fluency in the context of German foreign language learning. This study showed a significant gain in writing fluency among German language students when they selected their own topics for composition. The present study seeks to replicate and generalize the work of Bonzo to the Japanese EFL context. The study included a range of language learners in a Japanese engineering high school, who attend two main streams of English 
courses. One stream, taught by Japanese instructors in Japanese, focuses on reading and grammar, with writing playing a minor role in assessing students' understanding of grammatical structures or the content of their reading. The other stream is led by foreign instructors with a focus on oral communication. Fluency, in this context, is usually connected to oral fluency, and this takes priority over written fluency. Neither stream of English study does emphasize writing as a fluency building exercise; however, for the purpose of this study, six ten-minute timed writing sessions were conducted in the foreign instructor led courses to see if similar results to Bonzo's could be found among Japanese adolescent learners.

In line with Bonzo's (2008) adoption of Wolfe-Quintero, Inagaki, \& Kim's (1998) measure for fluency, Bruton \& Kirby (1987) acknowledge that the writing fluency of novice writers, "incorporates much of what traditional views of written fluency have characterized in emphasis on quantity and composing rate. That is, initial fluency involves writers' feeling comfortable with writing to the extent that they are able to write quickly without fear" (p. 92). Bonzo's paper, partially replicated in this current study, designs an opportunity to examine how student topic-selection, ownership over content, compared with a teacher-assigned topic, affects EFL learners written fluency, as measured through comparing quantity of unique words to total words produced.

This replication study posits one main research question, as an extension of the Bonzo (2008) study. Do teacher-selected versus student-selected writing topics have an effect on students' writing fluency? Supporting research questions specific to the Kanazawa Technical College (KTC) context are: (1) At KTC, are there interdepartmental differences in writing fluency for first and second year Skills students? (2) At KTC, are there differences in writing fluency between first- and second year Skills students?

\section{METHOD}

\section{Participants}

This writing fluency study consisted of 109 students at a five-year engineering school in Japan: 69 first year students from six sections of English Skills I, and 40 second year students from three sections of English Skills II at KTC. Global (G) Department students at KTC are required to take English classes with foreign teachers every year they are at KTC. The curriculum of the Global Department places a greater emphasis on English education. Students in the Mechanical (M) and Electrical (T) Departments are only required to take English classes for their first 3 years at KTC. However, all students have opportunities to participate in English language study and travel abroad programs in the United
States, New Zealand, and Southeast Asia.

\section{Writing Procedure}

For this study, participating students were divided into two groups according to their Skills teacher. These groups were composed of 54 students (group 1), and 55 students (group 2) respectively. Both groups contained all three departmental majors at KTC, and both groups contained about a 3:1 ratio of first and second year students, with group 1 containing $37 \%$ second year students, and group 2 containing $36 \%$.

All students in this study were asked to sign written consent forms before participating, and were given an explanation of the research and procedure in English, with some Japanese language instruction used for clarification. All students were asked to complete a bilingual Student Demographic Questionnaire, focused on the topics of academic and recreational writing, prior to the production of writing samples (see Appendix A). All students completed a ten-minute practice writing session where they were asked to choose their own topic, and to write silently for the duration of the sampling time. In Skills I class section, a native Japanese English teacher was present to translate the introduction and procedure of the project for students, to answer student questions, and to assist during the practice writing session.

A total of six 10-minute writing sessions were carried out weekly during the first 10 minutes of Skills I and II classes by each of the three teachers. Across the six weeks, topics alternated between teacher-selected and student-selected. Table 1 shows the schedule for writing topics for Groups 1 and 2 . Teacher-selected writing topics were derived from Bonzo's original study and agreed upon by the three participating teachers as relevant to students' lives and appropriate for the classroom context.

During writing sessions, students were instructed not to copy from each other, not to erase their work, to simply cross out any unwanted passage with a single line, and to continue writing as much as possible for the whole ten minutes. Students were instructed not to focus on grammar and syntax, but instead to just write down their thoughts as they thought of them. Students were not allowed to use dictionaries or smart phones for assistance, asked not to speak during the ten minutes, and were told that they would not be graded for any written production during the sampling time. See Appendix B for a copy of the student writing page used for each writing session.

\section{Post-writing Student Questionnaires}

After each ten-minute writing session, the students were given a bilingual post-writing questionnaire consisting of five questions on a Likert scale of one to five (one being strongly disagree; five being strongly agree). These questions addressed the topic, 
the writing process, and the difficulty of writing for the full ten minutes. This data was entered and analyzed for significant trends. See Appendix C for a copy of this questionnaire form.

Table 1. Schedule of Writing Topics for Group 1 and 2

\begin{tabular}{cll}
\hline WEEK & \multicolumn{1}{c}{ GROUP 1 } & \multicolumn{1}{c}{ GROUP 2 } \\
\hline 1 & Teacher-selected: Life after graduation & Student-selected Topic \\
2 & Student-selected Topic & Teacher-selected: Life after graduation \\
3 & Teacher-selected: Friends & Student-selected Topic \\
4 & Student-selected Topic & Teacher-selected: Friends \\
5 & Teacher-selected: Summer Vacation & Student-selected Topic \\
6 & Student-selected Topic & Teacher-selected: Summer Vacation \\
\hline
\end{tabular}

\section{Data Analysis}

After collecting each student sample, a wordprocessing program was used to type each student sample. During this time, lexical items were standardized, such as where multiple spelling variations of the same word were found. Students who did not complete all six ten-minute sessions due to school absence were processed, but not included in later calculations of the students' writing data. The UsingEnglish.com online text analyzer was used to find the total number of words per writing sample and the number of unique words per sample.

\section{Calculation of Frequency Index Scores}

The present study adopted the same formula for calculating fluency scores as Bonzo (2008). Using the number of unique words (U) per sample, and the total number of words $(\mathrm{T})$ from the same sample, the Fluency Index (FI) score was calculated using the formula below:

$$
\underline{F I=U \div \sqrt{2 T}}
$$

Bonzo referred to Arthur (1979) in support of this formula as he "found it was able to discriminate effectively between different writers when proportions were identical but length was different" (Bonzo, 2008, p. 728).

\section{RESULTS \\ Topic Choice and Writing Fluency}

In this study, a $t$-test of correlated samples demonstrated a significant difference $(\mathrm{p}=<0.0001)$ when comparing the mean FI scores of all participating students. Teacher-selected FI scores averaged $2.62 \quad(\mathrm{SD}=0.87)$, while student-chosen topic samples yielded an average of 2.77 ( $\mathrm{SD}=$ 0.89). This result shows support for this study's primary research question; student-selected writing topics allowed students to write more fluently than when they were given a teacher-selected topics, and supports Bonzo's (2008) finding about topic selection and writing fluency from a Japanese high school context (see Table 2).

Table 2. KTC student writing fluency by sample group

\begin{tabular}{lcccccc}
\hline & TS Topic Fluency Index & SS Topic Fluency Index & Mean $_{\mathbf{a}}-\mathbf{M e a n}_{\mathbf{b}}$ & $\mathbf{T}$ & df & Significance \\
\hline Group 1 & 2.58 & 2.64 & -0.0562 & -1.31 & 53 & $\mathrm{p}=0.195845$ \\
\hline Group 2 & 2.66 & 2.86 & -0.2072 & -4.19 & 54 & $\mathrm{p}=0.000104$ \\
\hline ALL & 2.62 & 2.77 & -0.1506 & -3.94 & 108 & $\mathrm{p}=0.000145$ \\
\hline TS = Teacher-selected & & $\mathrm{SS}$ = Student-selected & & & &
\end{tabular}

\section{Fluency Scores Accross Engineering Majors at KTC}

To examine the differences in written fluency between students in the $\mathrm{G}, \mathrm{M}$ and $\mathrm{T}$ Departments at KTC, mean FI scores were calculated. When students were allowed to choose their own topics for writing, student samples from two of the three departments yielded higher FI scores (see Table 3).

This data also indicates that the $\mathrm{G}$ department had the highest student writing fluency of the three departments on both student-selected and teacherselected topics, with a mean teacher selected FI score of (2.72), and a self-selected score of (2.92).
The $\mathrm{M}$ department had a higher mean FI score (2.77) than the $\mathrm{T}$ department (2.65) on self-selected topics, but

the $\mathrm{T}$ department had a higher FI score (2.63) than the $\mathrm{M}$ department (2.53) on teacher-selected topics (see Table 3).

It is important to note that $\mathrm{T}$ department students' writing samples did not produce a statistically significant increase in fluency on selfselected topics (see Table 3), though their FI scores remain of interest when compared to other departments' scores.

Table 3. KTC student writing fluency by Engineering Department

\begin{tabular}{lcccccc}
\hline & TS Topic Fluency Index & SS Topic Fluency Index & Mean $_{\mathbf{a}}-\mathbf{M e a n}_{\mathbf{b}}$ & $\mathbf{t}$ & df $_{\text {S }}$ Significance \\
\hline Global & 2.72 & 2.92 & -0.2018 & -3.45 & 32 & $\mathrm{p}=0.001594$
\end{tabular}




\begin{tabular}{|c|c|c|c|c|c|c|}
\hline Mechanical & 2.53 & 2.77 & -0.2413 & -3.09 & 37 & $p=0.003789$ \\
\hline Electrical & 2.63 & 2.65 & -0.0153 & -0.29 & 37 & $\mathrm{p}=0.773435$ \\
\hline
\end{tabular}

\section{Fluency}

Scores Across Accross Grade Levels 1 and 2

First year students in this study had an average FI score of $2.68(\mathrm{SD}=0.92)$ for student-selected writing topic samples, whereas second year students had an average of $2.92(\mathrm{SD}=0.82)$. When teachers chose the topics for student writing, the first year students had an average FI score of 2.53 (SD =
0.88 ); second year students average was 2.78 (SD = 0.82).

In addition, it is important to note that when analyzed separately, second year students' writing samples did not produce a statistically significant increase in fluency on self-selected topics.

Table 4. KTC student writing fluency by skills year

\begin{tabular}{lcccccc}
\hline & TS Topic Fluency Index & SS Topic Fluency Index & Mean $_{\mathbf{a}}-\mathbf{M e a n}_{\mathbf{b}}$ & $\mathbf{t}$ & df $_{c}$ Signficance \\
\hline Year 1 & $\mathbf{2 . 5 3}$ & $\mathbf{2 . 6 8}$ & -0.1549 & -3.87 & 68 & $\mathrm{p}=0.000247$ \\
\hline Year 2 & $\mathbf{2 . 7 8}$ & $\mathbf{2 . 8 5}$ & -.0945 & -1.56 & 39 & $\mathrm{p}=0.126831$ \\
\hline TS = Teacher-selected & SS = Student-selected & & & & &
\end{tabular}

\section{Student Questionnaire Results}

As mentioned in the section 4.2, students were asked to complete a two-part Student Demographic Questionnaire. In both of these parts, students were asked to assess themselves using either a three- or five part Likert scale. Included below are students' responses to questions 4 and 7 from the English writing mechanics sections (see Table 5) and questions $6,7,10,11,12$ and 17 from the general writing skills and strategies sections (see Table 6).

Table 5. Student demographic questionnaire results; English writing mechanics by department.

\begin{tabular}{llllll}
\hline \multicolumn{1}{c}{ Survey Question } & $\mathrm{G}$ & $\mathrm{M}$ & $\mathrm{T}$ & Year 1 & Year 2 \\
\hline 4. I can express my opinion in English. & 1.81 & 1.90 & 1.94 & $\mathbf{1 . 7 8}$ & $\mathbf{2 . 1 0}$ \\
7. I can write quickly in English. & 1.90 & 1.58 & 1.54 & $\mathbf{1 . 5 2}$ & $\mathbf{1 . 9 9}$ \\
\hline
\end{tabular}

*1 (No) 2 (Maybe/Sometimes) 3 (Yes)

Overall, there was little difference among departments in the students' self-assessment of their ability to express their opinion, though the global department average was slightly higher than the other two departments (Table 5). There was an increase in average between first and second year students in their answers to questions 4 and 7 .

In General Writing Skills and Strategy section, slight differences appear between the grade streams and concern questions that reflected student selfreliance (questions 10, 11, 12, 17 in Table 6).

Table 6. Student demographic questionnaire results; general writing skills and strategy by department.

\begin{tabular}{|c|c|c|c|c|c|}
\hline Survey Question & $\mathrm{G}$ & $\mathrm{M}$ & $\mathrm{T}$ & Year 1 & Year 2 \\
\hline 6. I think about ideas before I write & 3.19 & 3.04 & 3.17 & 3.13 & 3.15 \\
\hline $\begin{array}{l}\text { 7. I think about the teacher's directions carefully } \\
\text { before I write. }\end{array}$ & 3.43 & 3.25 & 3.55 & 3.39 & 3.44 \\
\hline $\begin{array}{l}\text { 10. If I can't think of a word, I use a different word } \\
\text { with the same meaning }\end{array}$ & 2.86 & 3.31 & 3.22 & 3.09 & 3.22 \\
\hline $\begin{array}{l}\text { 11. If I can't think of a word, I ask the teacher for } \\
\text { Help }\end{array}$ & 3.38 & 3.71 & 3.76 & 3.58 & 3.68 \\
\hline $\begin{array}{l}\text { 12. If I can't think of a word, I ask a classmate or use } \\
\text { my dictionary }\end{array}$ & 3.60 & 3.76 & 4.06 & 3.73 & 3.95 \\
\hline 17. I worry about making mistakes when I write & 2.97 & 3.37 & 3.66 & 3.32 & 3.35 \\
\hline
\end{tabular}

\section{DISCUSSION}

The results of this study show, similar to Bonzo's 2008 work, in some instances, offering students' choice in writing topic can lead to a higher fluency score as measured by higher ratio of unique words to total words. As well, in an earlier replication of the Bonzo (2008) study, Dickinson (2014) found that "when learners [were] given control over topic choice, they [were] able to write about something both more familiar and meaningful to them" (p. 21).
This suggests overall that in all three studies, students who were able to write on their own topics would be able to find more meaning in the writing assignment. This meaning, Dickinson points out, "may lead to increased fluency as learners can perhaps more easily access the lexis they need to express themselves when writing about things they have previously spoken or thought deeply about" (p. 21). As educators, this targeting of student interest topics and the potential for more fluent 
communication as the result of in-class practice of important life topics is aligned with communicative teaching goals. Assignments that focus both on fluency building and student interest allow students valuable rehearsal time for real-world L2 encounters in which they will be able to better express those subjects that they find most important.

Unlike Bonzo's study, which analyzed writing complexity in addition to fluency and found that "as fluency...increases, so does the potential for increased complexity" (2008, p. 730), this study was limited by its singular focus on fluency. Each student drew on a range of strategies and experiences to produce text, each permitting a different amount of time for planning and revision undetected by the fluency index scores. Some students used concept maps rather than the task's expected sentences and paragraphs, others made lists, and still others had rich, academically formatted essays. While all of these forms of writing may show varying levels of grammatical complexity, the fluency index allowed us only to see what students produced in terms of total words and unique words. Further research into text complexity and writing strategies employed during writing would enhance this work.

When considering how Bonzo's study results in a German EFL context compare to this Japanese EFL context, it is important to consider that Japanese national educational systems are likely to place heavy emphasis on students being able to perform on strictly formatted tasks that have been heavily prompted by the teacher. In this system, students are not given many chances to self-select their topics nor freedom in how they complete writing tasks. This impacts the familiarity and comfort level for students who are then asked, in a foreign language setting, to start producing their own text with little guidance about what to write, only to keep writing. Especially in classroom curriculums that don't often utilize free writing and fluency building activities, teachers can not assume that students will be able to complete these tasks without specific teacher instruction and modeling. Therefore, in this study, it is important to note all three teachers spent time working to help student to be able to understand what was wanted of them when teachers said to 'free write' during the practice writing sessions.

In Bonzo and Dickinson's previous studies and the current study, self-determination theory, as discussed by Deci \& Ryan (2011), may offer some explanation to the correlation between student selfselected topics and increased fluency index scores. Self-determination theory posits that intrinsic motivation derives, in part, from the degree of autonomy perceived by a learner. In other words, "to the extent that events such as choice lead to an internal perceived locus of causality and support the autonomy need [in humans], they will enhance intrinsic motivation" (p. 418). It follows that enhanced intrinsic motivation will lead to greater engagement and buy-in into an activity. When students are able to determine their own topics for writing, their ownership of the piece increases, and so does their motivation to write more. In this study, teacher-selected topics were also created with the students' own interests and concerns in mind, which sets it apart from some textbooks or courses in which topics are randomly or abstractly determined. As mentioned in section 4.2 of the writing procedure, teacher-selected topics were chosen based on relevance to students' lives and appropriateness for the classroom context. This may account for the lack of significant increase in the fluency scores of second year students between teacher-selected and self-selected topics.

There are several noteworthy limitations to this study. First of all, as mentioned above, this study focuses solely on a comparison of written fluency between teacher-selected and self-selected writing topics. It does not seek to address complexity of forms, nor to develop a much needed understanding of how the overall process of developing writing fluency unfolds. A second consideration that could fuel an entirely new study of its own is how confidence building and L2 written fluency are linked. Though we conducted student surveys after each writing session, more explicit research should be conducted to understand how students' confidence, affect, and enjoyment of English might be influenced by increases in fluency. Finally, because this was a short-term study, conducted over a six week sampling period, results give a small window into the overall performance of students. Extensions to include end of the school year sampling, as well as tracking the same students through multiple years of English study, would expand the scope and underscore findings.

In agreement with Bonzo's conclusion, the results of this study support the notion that free writing activities that focus on building fluency, and those that acknowledge student choice, deserve a place in all foreign language classrooms. From Bonzo's original study, through a series of replications made by international teachers (including Dickinson, 2014), and through the findings of this study, the benefits of self-selected topics include increased fluency and increased meaning to classroom writing tasks. A balanced language curriculum provides students opportunities to practice and grow as language users through ownership over the topics. These opportunities allow them to take risks and create their own conceptualization of language, and bridge the gap between what students are taught in the classroom and what learners need to become proficient language users. 


\section{Acknowledgements}

The authors of this replication study wish to acknowledge and give special thanks for the extensive knowledge and consistent support provided by Professor Gregory Sholdt through his invaluable Quantitative Research Training Project 2014-2015. The authors would like to acknowledge the work of Bonzo for its inspirational and informative role in this study. The authors would also like to thank Kanazawa Technical College for its support of academic research by its teaching faculty. Finally, the authors wish to thank Professor Takako Utsunomiya for her language and professional support during the execution and manuscript writing phases of this study.

\section{REFERENCES}

Arevart, S. \& Nation, P. (1991). Fluency improvement in a second language. RELC Journal: A Journal of Language Teaching and Research, 22(1), pp. 84-94.

Bonzo, J. D. (2008). To assign a topic or not: observing fluency in intermediate foreign language writing. Foreign Language Annals, 41, pp. 722-735.

Brière, E.J. (1966). Quantity before quality in second language composition. Language Learning, 16, pp. 141-151.

Bruton, D.L. \& Kirby, D.R. (1987). Written fluency: Didn't we do that last year? The English Journal, 76, pp. 89-92.

Connor-Linton, J. (1995). Cross-cultural comparison of writing standards: American ESL and Japanese EFL." World Englishes, 14(1), pp. 99-115.

Cordova, D.I. \& Lepper, M.R. (1996). Intrinsic motivation and the process of learning: Beneficial effects of contextualization, personalization, and choice. Journal of Educational Psychology, 88(4), pp. 715-730.

Deci, E.L. \& Ryan, R.M. (2011). SelfDetermination theory. Handbook of theories of social psychology: Collection: 1 \& 2, pp. 416433.

Dickinson, Paul. (2014). The effect of topicselection control on EFL writing fluency.
Journal of Niigata University of International and Information Studies, 17, pp. 15-25.

Erazmus, E. (1960). Second language composition teaching at the intermediate level. Language Learning, 10, pp. 25-31.

Heilenman, L.K. (1991). Writing in foreign language classrooms: process and reality. Georgetown University Round Table on Language and Linguistics 1991 (pp. 273-288). Washington, DC: Georgetown University Press.

Housen, A., \& Kuiken, F. (2009). Complexity, accuracy, and fluency in second language acquisition. Applied linguistics, 30(4), 461473.

Kobayakawa, M. (2011). Analyzing writing tasks in Japanese high school textbooks: English I, II, and writing. JALT Journal, 33(1), pp. 27 - 48.

Matsuda, P.K. (2003). Second language writing in the twentieth century: A situated historical perspective. In Kroll, B. (Ed), Exploring the Dynamics of Second Language Writing, 15 34. Cambridge, U.K.: Cambridge University Press.

Nation, P. (1996). The four strands of a language course. TESOL in Context, 6(2), pp. 7-12.

Perlmuter, L.C. \& Monty, R.A. (1977). The importance of perceived control: Fact or fantasy? American Scientist, 65(6), pp. 759765.

Pincas, A. (1962). Structural linguistics and systematic composition teaching to students of English as a foreign language. Language Learning, 7, pp. 185-195.

Reichelt, M.A. (2001). A critical review of foreign language writing research on pedagogical practices. Modern Language Journal, 85, pp. 578-598.

Robb, T., Ross, S., \& Shortreed, I. (1986). Salience of feedback on error and its effect on EFL writing quality. TESOL Quarterly, 20, pp. 8395.

Wolfe-Quintero, K., Inagaki, S., \& Kim, H. (1998). Second language development in writing: Measures of fluency, accuracy \& complexity. Honolulu, HI: University of Hawaii Press. 


\section{Appendix A: Student Demographic Questionnaire}

Self-Assessment of English Writing \& Learning Skills

英語のライティングと学習能力の自己評価

Please rate your abilities for each of the items below on a scale between 1 and 3 . Circle your choice.

以下の項目に対して、1 から 3 で自分の能力を評価して下さい。選んだものに丸をつけて下さい。

$$
\begin{array}{ll}
1=\text { No } & 1=\text { } \\
2=\text { Maybe/Sometimes } & 2=\text { たぶん/時々 } \\
3=\text { Yes } & 3=\text { はい }
\end{array}
$$

\begin{tabular}{|c|c|c|c|}
\hline \multicolumn{3}{|c|}{ English Writing Mechanics } \\
\hline 1. I can write a topic sentence in English. 英語でトピックセンテンス(主題文)が書る。 & 1 & 2 & 3 \\
\hline 2.I can write a paragraph in English. 英語でパラグラフ(一段落)が書ける。 & 1 & 2 & 3 \\
\hline 3.I can write a conclusion sentence in English. 英語で結論の文が書ける。 & 1 & 2 & 3 \\
\hline 4.I can express my opinion in English. 英語で自分の意見を表現できる。 & 1 & 2 & 3 \\
\hline 5.I can use a variety of English tenses in writing. & 1 & 2 & 3 \\
\hline ライティング英語の色々な時制を使う事ができる。 & & \\
\hline 6. I can use good spelling, capitalization and punctuation in English writing. & 1 & 2 & 3 \\
英語のライティングでスペル、大文字、句読点を正しく使える。 & & \\
\hline 7. I can write quickly in English. 英語で速く書ける。 & 1 & 2 & 3 \\
\hline 8. I can improve my own writing, fix my problems. 自分の文を直す事ができる。 & 1 & 2 & 3 \\
\hline
\end{tabular}

Comments: (For example, if you answered “no” above, why “no”?) コメント(例えば、もし「いいえ」と 答えた人は、理由は?) 
Please rate your abilities for each of the items below on a scale between 1 and 5 . Circle your choice.

下記の項目に対して、1 から 5 で自分の能力を評価して下さい。選んだものに丸をつけて下さい。

$$
\begin{aligned}
& 1=\text { Never } \quad 1=\text { 全くない } \\
& 2=\text { Rarely } 2 \text { =めったにない } \\
& 3=\text { Sometimes } \quad 3=\text { 時々 } \\
& 4 \text { = Often } \quad 4=\text { よくある } \\
& 5 \text { = Most often/always } 5=\text { ᄃてもよくある/いもある }
\end{aligned}
$$

\begin{tabular}{|c|c|c|c|c|c|}
\hline \multicolumn{6}{|l|}{ General Writing Skills and Strategies (English or Japanese) } \\
\hline 1. I write in Japanese a lot. 日本語で文章をたくさん書く。 & 1 & 2 & 3 & 4 & 5 \\
\hline 2. I write in English a lot. 英語で文章をたくさん書く。 & 1 & 2 & 3 & 4 & 5 \\
\hline 3.I write in English in my free time. 暇な時、英語で文章を書く。 & 1 & 2 & 3 & 4 & 5 \\
\hline 4.I use an English-Japanese dictionary. 英和辞典を使う。 & 1 & 2 & 3 & 4 & 5 \\
\hline 5.I read English in my free time. 暇な時、英語の文章を読む。 & 1 & 2 & 3 & 4 & 5 \\
\hline 6. I think about ideas before I write. 書く前にアイデアを考える。 & 1 & 2 & 3 & 4 & 5 \\
\hline $\begin{array}{l}\text { 7. I think about the teacher’s directions carefully before I write. } \\
\text { 書く前に注意深く先生の指示について考える。 }\end{array}$ & 1 & 2 & 3 & 4 & 5 \\
\hline $\begin{array}{l}\text { 8. I look at class materials on the topic before I write. } \\
\text { 書く前に、テーマに関するクラス教材を見る。 }\end{array}$ & 1 & 2 & 3 & 4 & 5 \\
\hline 9. I enjoy writing in Japanese. 日本語で文章を書く事が好き。 & 1 & 2 & 3 & 4 & 5 \\
\hline $\begin{array}{l}\text { 10. If I can't think of a word, I use a different word with the same meaning. } \\
\text { 単語が思いつかない時、同じ意味の別の単語を使う。 }\end{array}$ & 1 & 2 & 3 & 4 & 5 \\
\hline $\begin{array}{l}\text { 11. If I can’t think of a word, I ask the teacher for help. } \\
\text { 単語が思いつかない時、先生に聞く。 }\end{array}$ & 1 & 2 & 3 & 4 & 5 \\
\hline $\begin{array}{l}\text { 12. If I can’t think of a word, I ask a classmate or use my dictionary. } \\
\text { 単語が思いつかない時、同級生に聞くか辞書を使う。 }\end{array}$ & 1 & 2 & 3 & 4 & 5 \\
\hline $\begin{array}{l}\text { 13. I think writing in English in class can help me in the future. } \\
\text { クラスで英文を書く事は、自分の将来に役立つと思う。 }\end{array}$ & 1 & 2 & 3 & 4 & 5 \\
\hline $\begin{array}{l}\text { 14. I tell myself “You can do it!” when I'm learning English. } \\
\text { 英語を学んでいる時、「自分はできる」と自分に言い聞かせる。 }\end{array}$ & 1 & 2 & 3 & 4 & 5 \\
\hline $\begin{array}{c}\text { 15. I try to make writing fun for myself. } \\
\text { 書く事を、自分にとって楽しいものにしようと努めている。 }\end{array}$ & 1 & 2 & 3 & 4 & 5 \\
\hline $\begin{array}{l}\text { 16. I read my writing again after I finished. } \\
\text { 書き終えた後、自分の文章をもう一度読む。 }\end{array}$ & 1 & 2 & 3 & 4 & 5 \\
\hline 17. I worry about making mistakes when I write. & 1 & 2 & 3 & 4 & 5 \\
\hline
\end{tabular}


書く時、失敗する事を気にする。

Comments: (For example, if you answered "never" above, why "never"?)

コメント(例えば、「全くない」と答えた人は、理由は?

Appendix B: Student Writing Sample Page (Teacher-selected topic shown)

\begin{tabular}{|l|l|}
\hline$T$ & \\
\hline$U$ & \\
\hline
\end{tabular}

DATE

ID NUMBER

CLASS

Free Write Topic: Choose any topic that you like

(Continue on back if necessary) 


\section{Appendix C: Student Post-Writing Questionnaire}

Date:

Free Writing: Post-Activity Questionnaire

ID:

Class:

Topic(話題):

\begin{tabular}{|c|c|c|c|c|}
\hline $\begin{array}{c}\text { Strongly Disagree } \\
\text { 全くそう思わない }\end{array}$ & $\begin{array}{c}\text { Disagree } \\
\text { こう思わない }\end{array}$ & $\begin{array}{c}\text { Neutral } \\
\text { ビちらでもない }\end{array}$ & $\begin{array}{c}\text { Agree } \\
\text { そう思う }\end{array}$ & $\begin{array}{c}\text { Strongly Agree } \\
\text { 非常にそう思う }\end{array}$ \\
\hline 1 & 2 & 3 & 4 & 5 \\
\hline
\end{tabular}

1. It was easy to keep writing for the full 10 minutes.

10分間をすべて使って書き続けることは簡単だった

2. I didn't know the right English vocabulary to express my ideas about this topic.

この話題について自分の考えを表す適切な英語の語彙がわからなかった

3. This topic is something I often think about outside this class.

この話題は（この）授業時間外で私がいつも考えていることである

4. It was difficult to think of things related to this topic to write about.

この話題に関連する事柄を書くために何かを思いつくことが難しかった

5. It was easy to put my ideas about this topic into English sentences.

この話題に関する自分の考えを英語の文章にすることは簡単だった

Share any additional thoughts on writing about this topic in English.

この話題について文章を書くことについて何か追加すべき考えや思いがあれば、英語で書いてくださ い。 